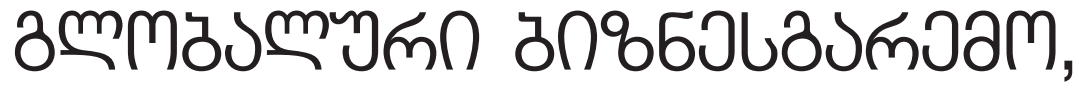

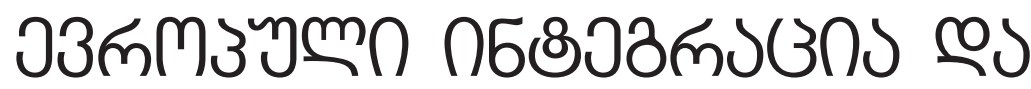

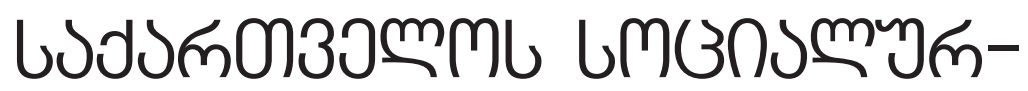

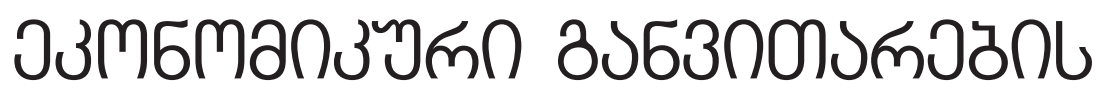

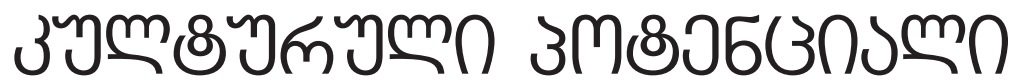

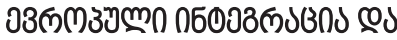

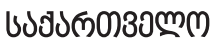

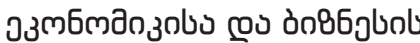

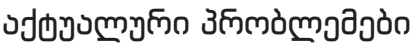
ammòumnosuzool

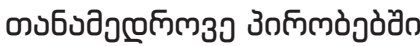

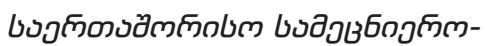

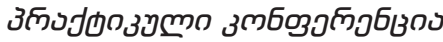

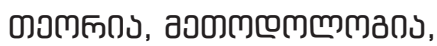

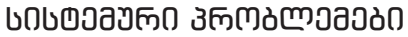

https://doi.org/10.35945/gb.2016.01.002

\section{0 зоৎоग6১ว30ल0}

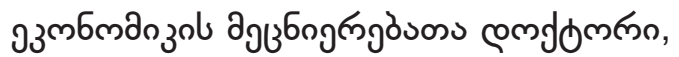

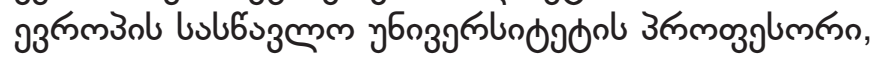

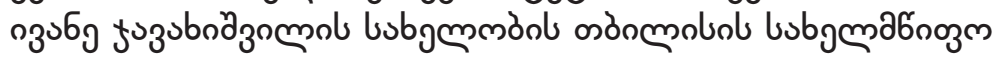

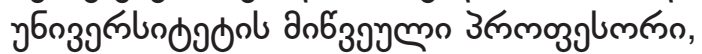

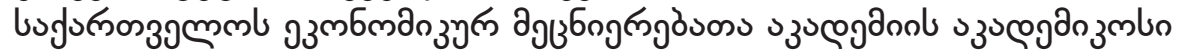

Lد33د6dm ln\&8y3jön:

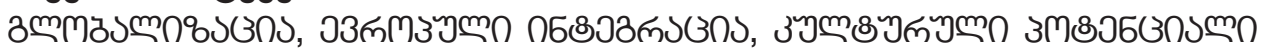

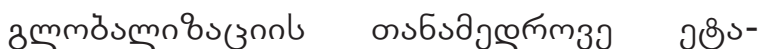

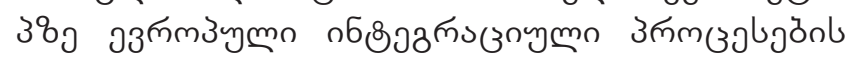

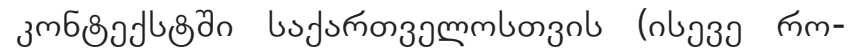

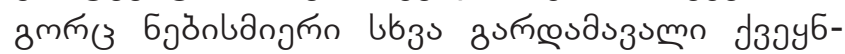

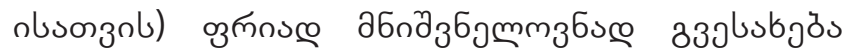

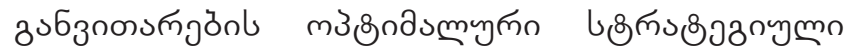

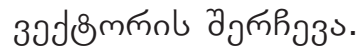

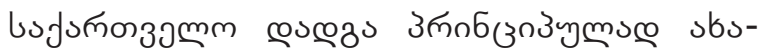

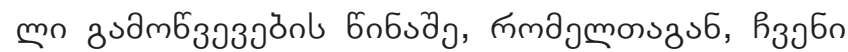

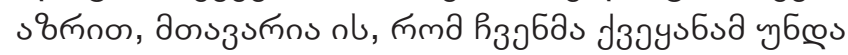

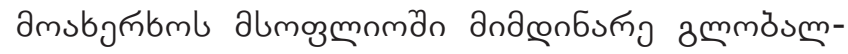

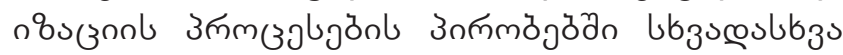

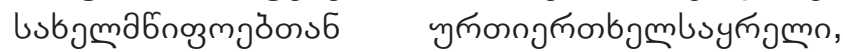

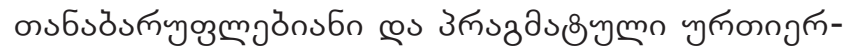

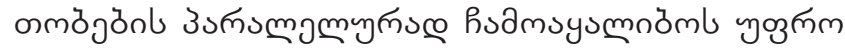

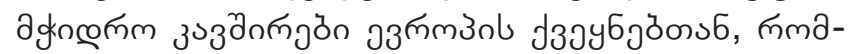

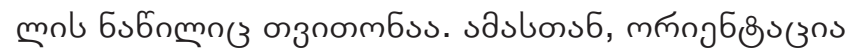

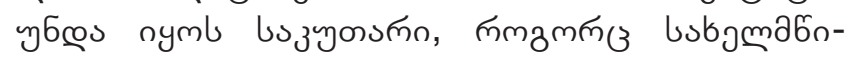

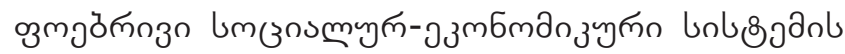

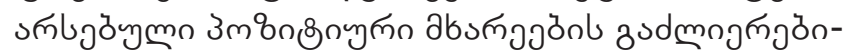

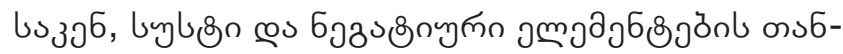

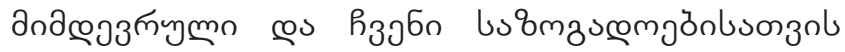

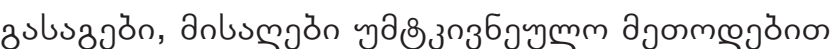

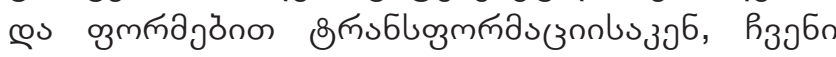

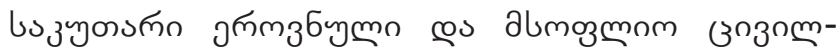

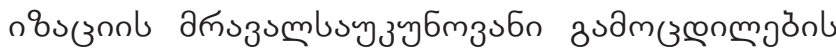

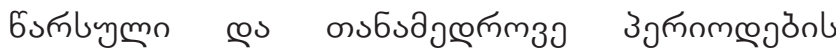

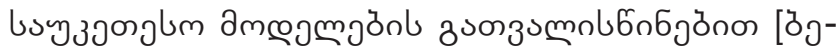

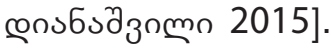

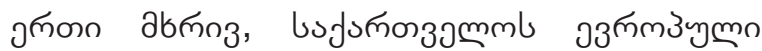

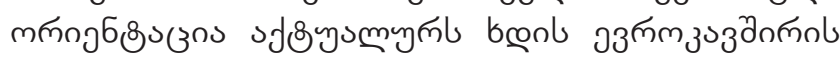

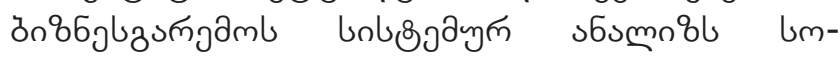
золмуyп-

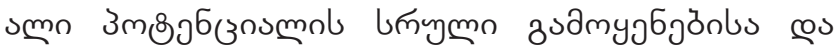

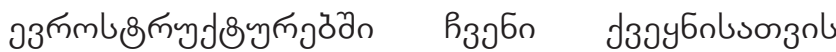

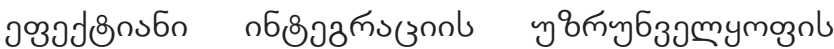

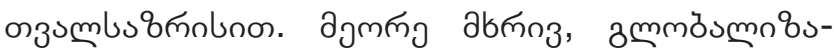

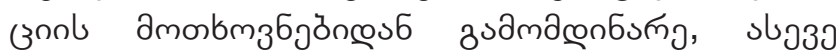

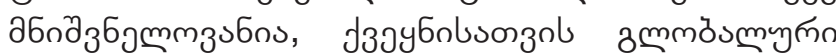

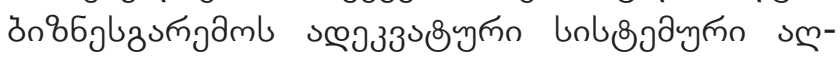

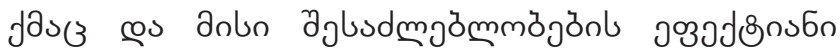

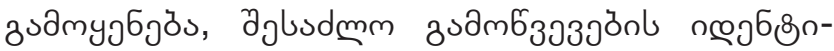

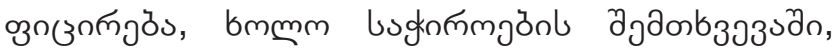

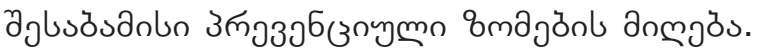




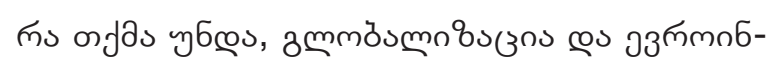

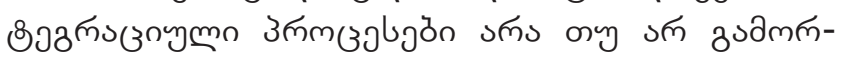

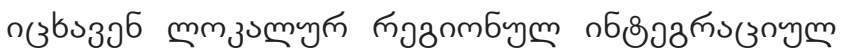

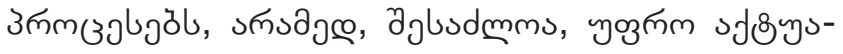
myূا bœns6 dson.

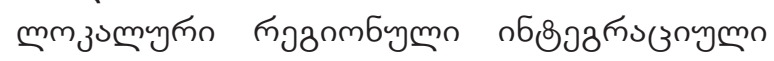

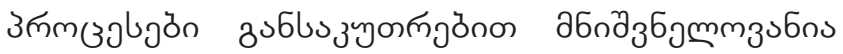

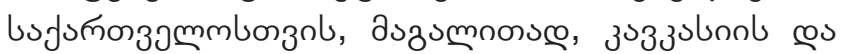

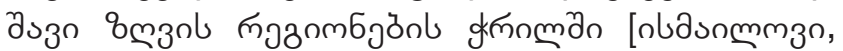
3ь3งзs 2009; Беридзе 2007].

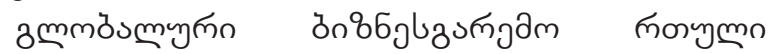

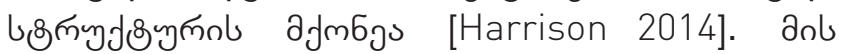

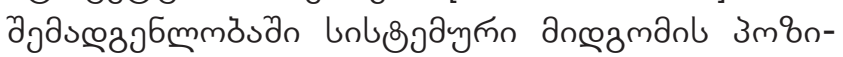

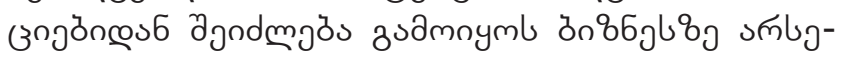

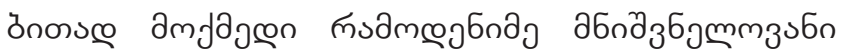

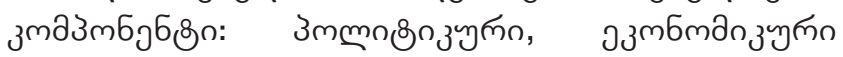

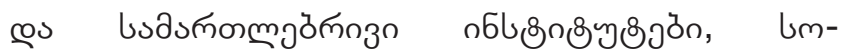

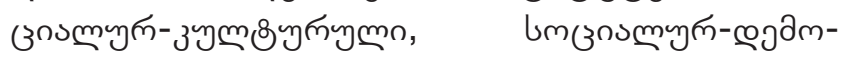

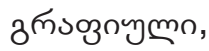

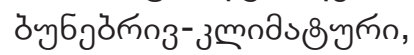

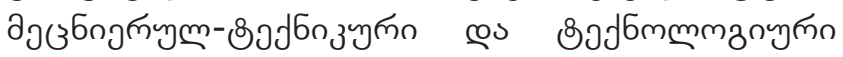

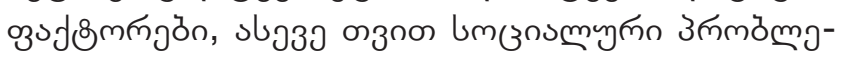

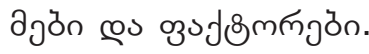

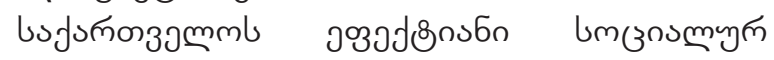

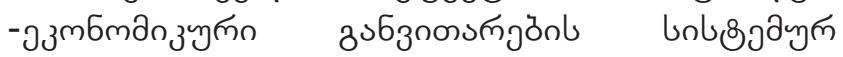

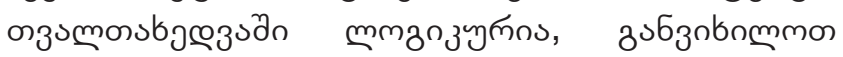

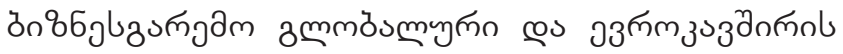

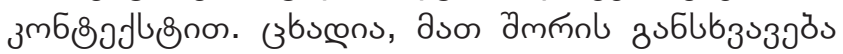

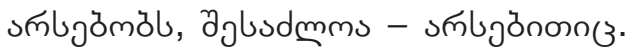

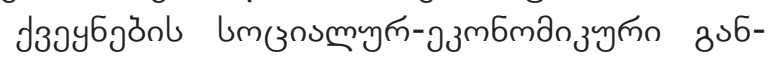

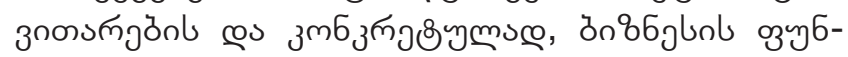

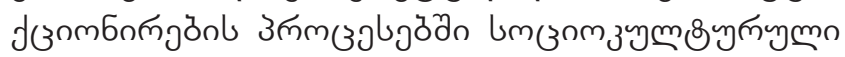

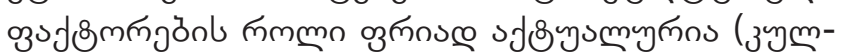

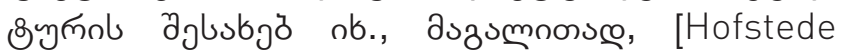
1980; mns6œol 1994; Шварц 2008; Инглхарт, Вельцель 2011; Культура имеет значение. Каким образом ценности способствуют общественному прогрессу 2002; Hall\&Hall 1990; Тромпенаарс, Хампден-Тернер 2004; Ясин

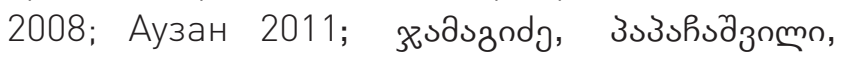

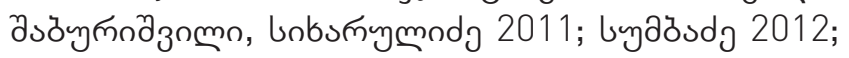

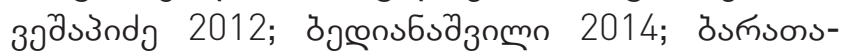

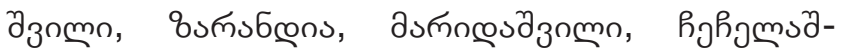

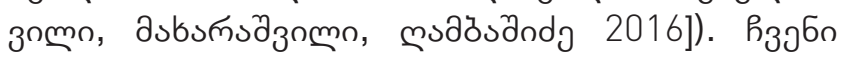

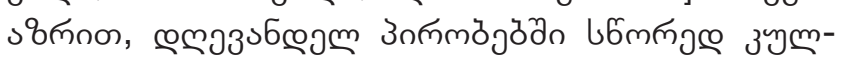

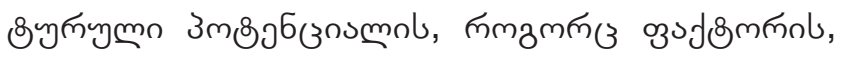

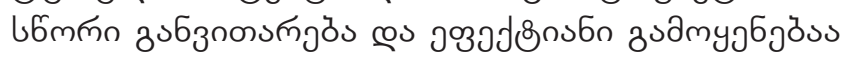

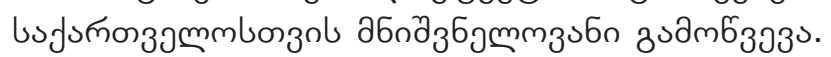

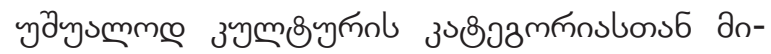

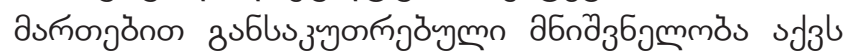

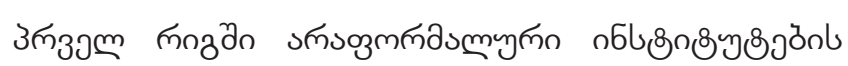

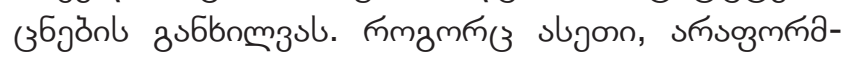

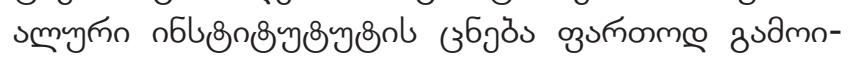

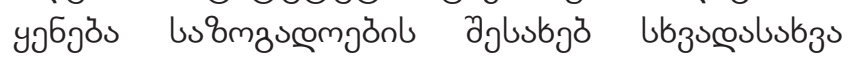

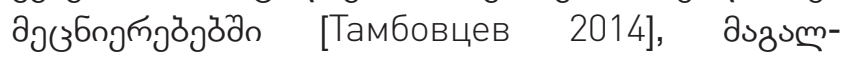

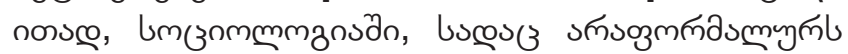

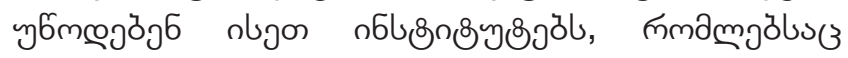

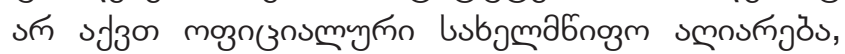

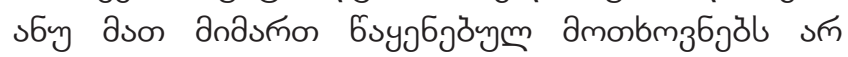

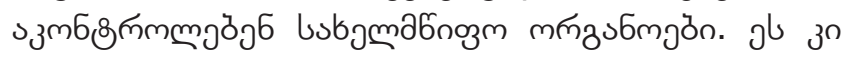

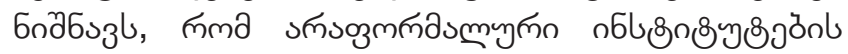

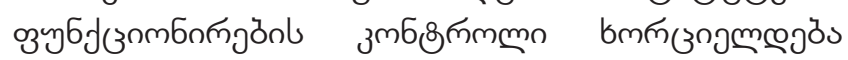

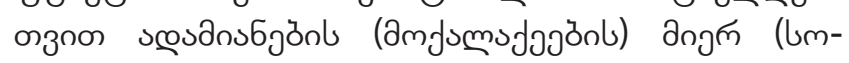

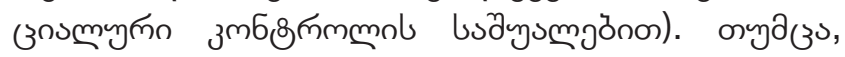

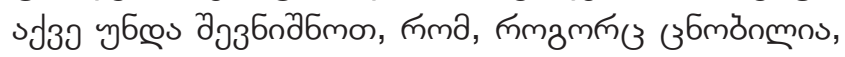

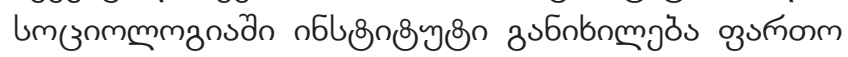

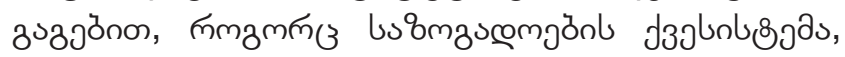

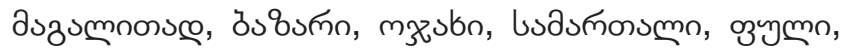

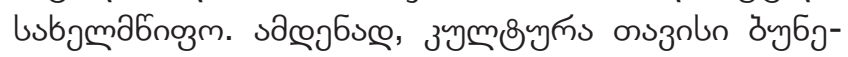

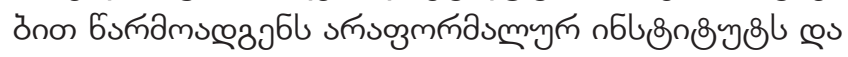

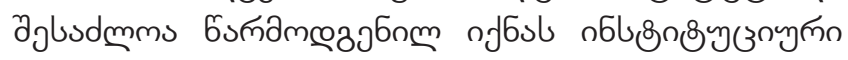

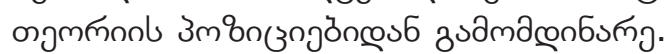

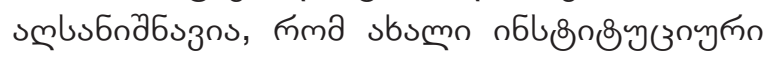

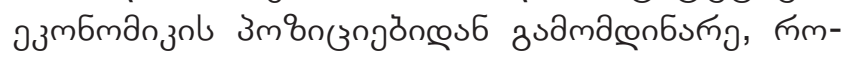

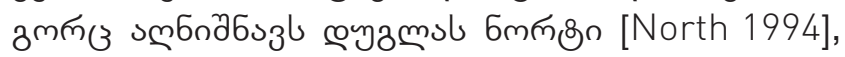

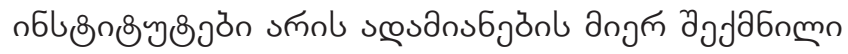

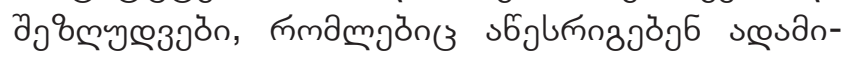

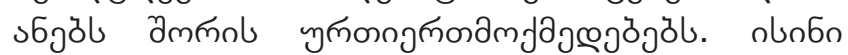

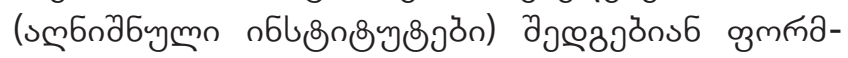

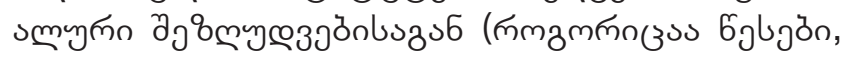

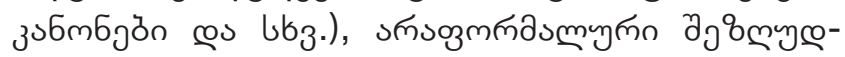

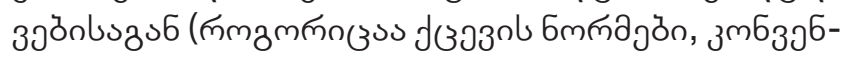

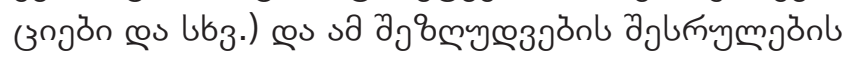

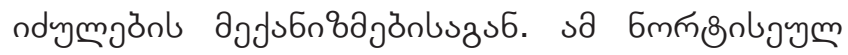

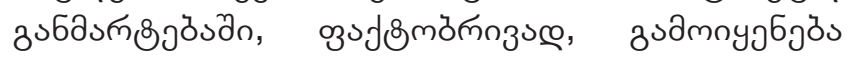

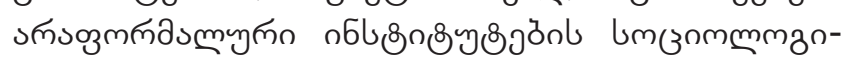

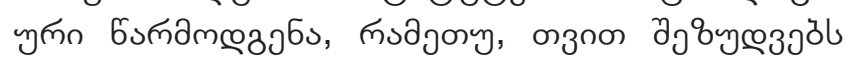

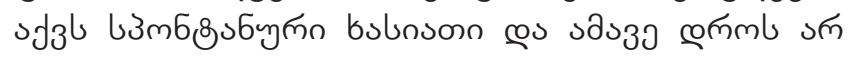

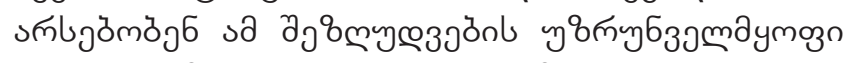

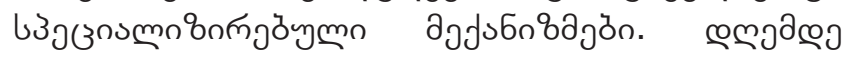

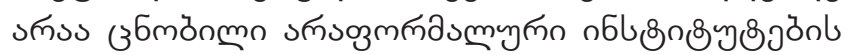

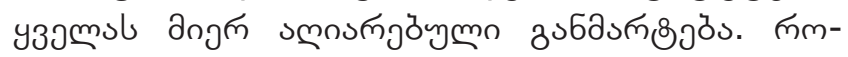

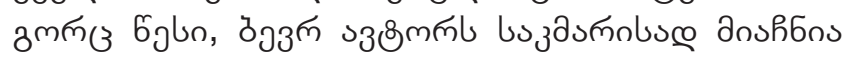

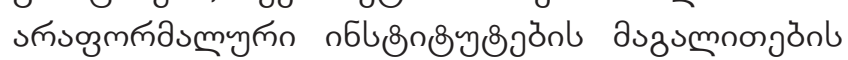

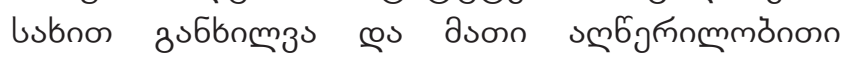

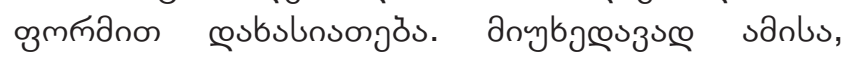

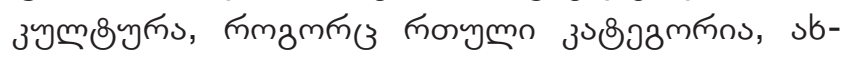

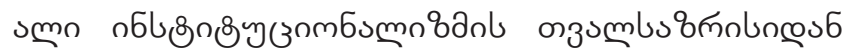

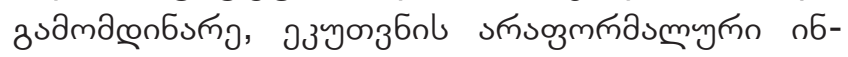




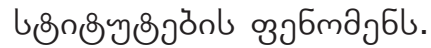

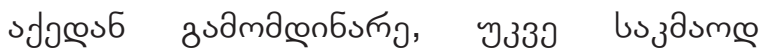

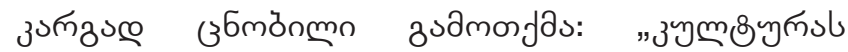

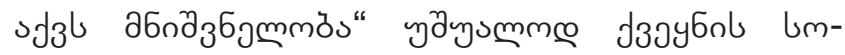

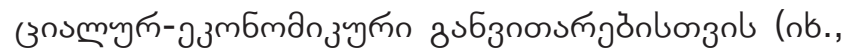
дззимполю, [Культура имеет значение. Каким образом ценности способствуют общес-

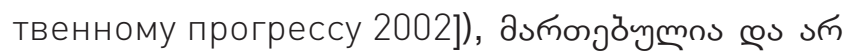

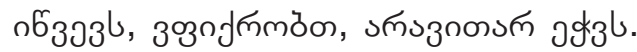

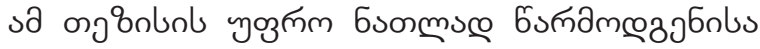

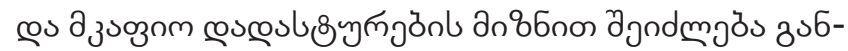

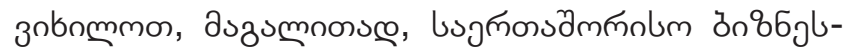

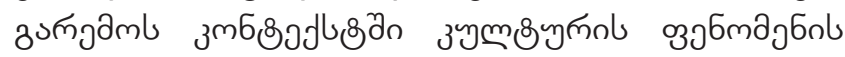

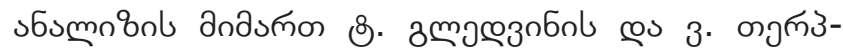
bonmol [Gladwin, Terpstra 1978] unbsjaym

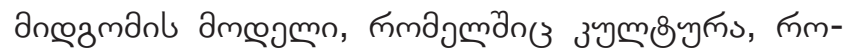

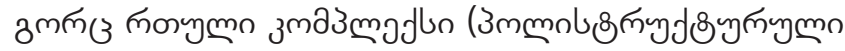

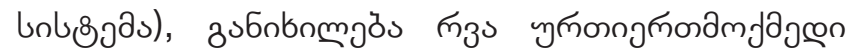

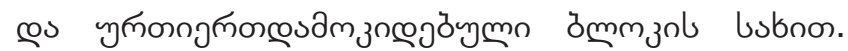

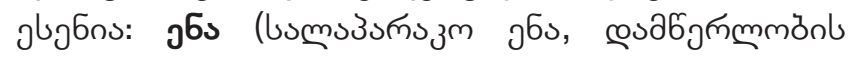

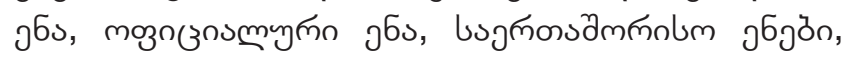

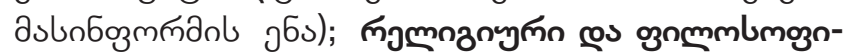

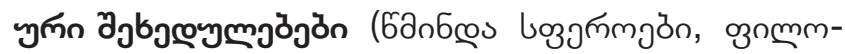

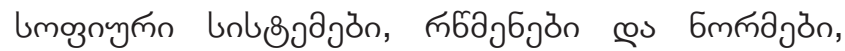

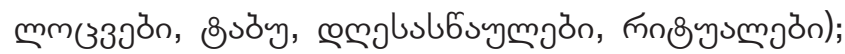

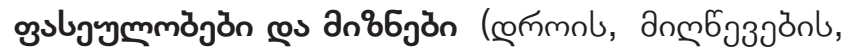

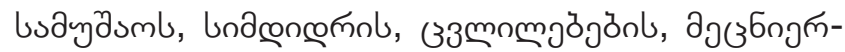

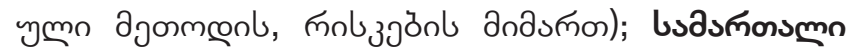

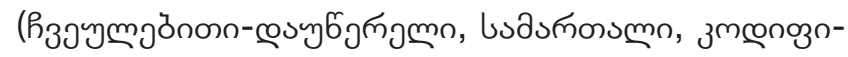

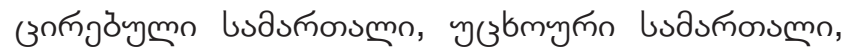

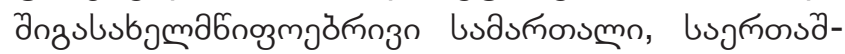

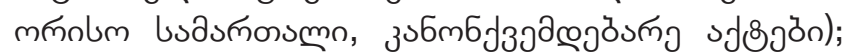

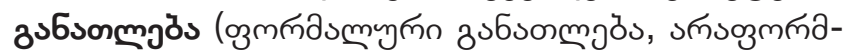

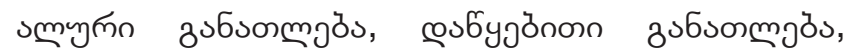

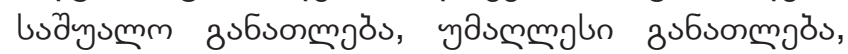

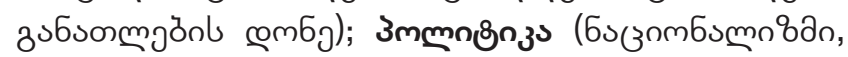

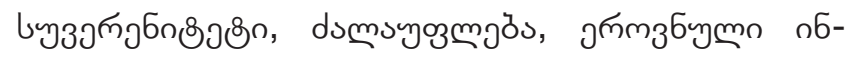

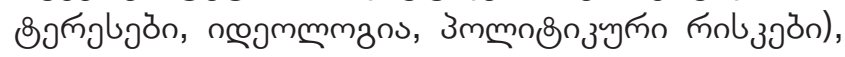

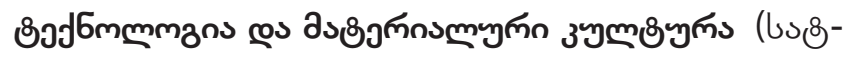

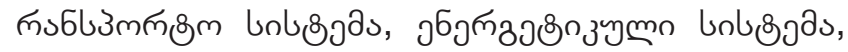

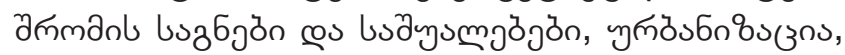

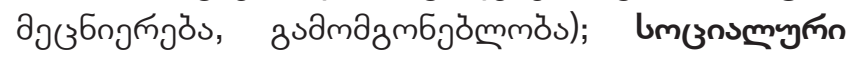

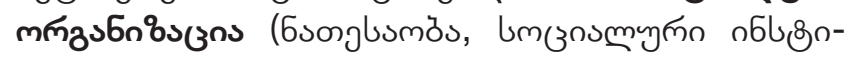

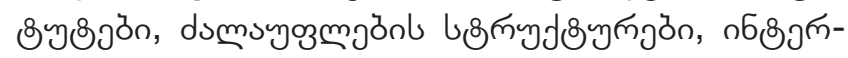

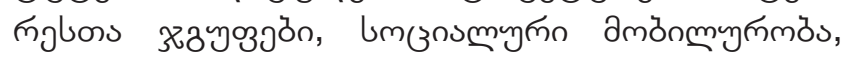

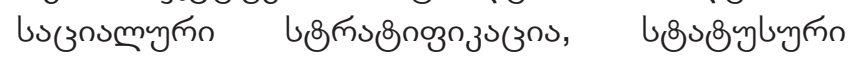
unb8jajon).

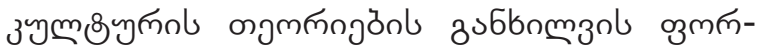

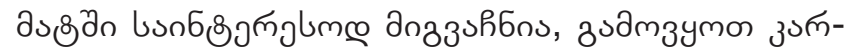

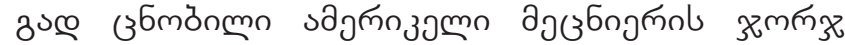

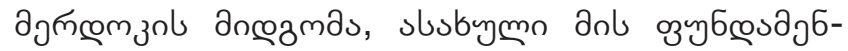

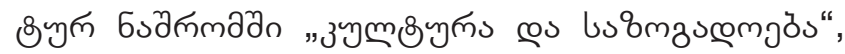

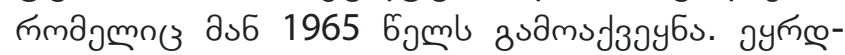

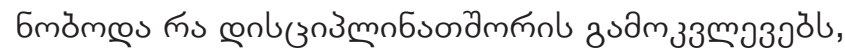

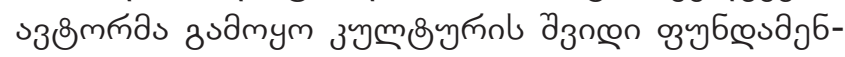

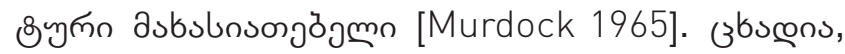

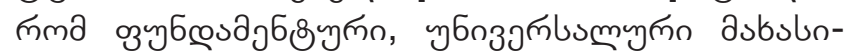

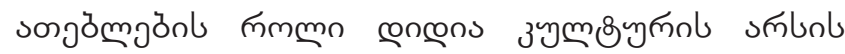

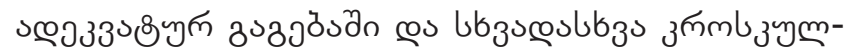

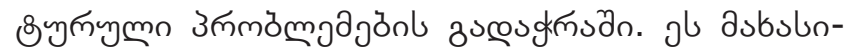

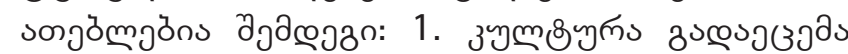

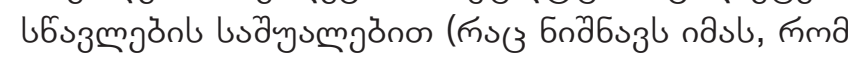

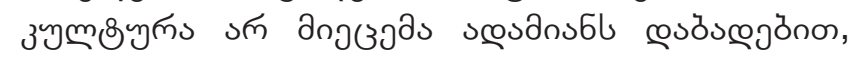

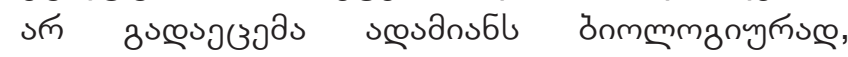

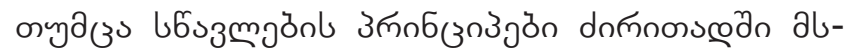

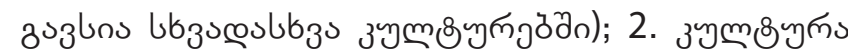

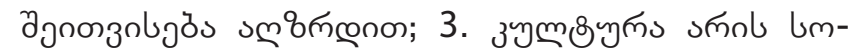

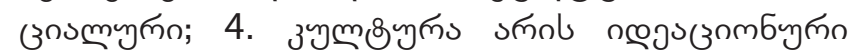

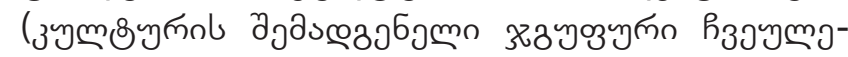

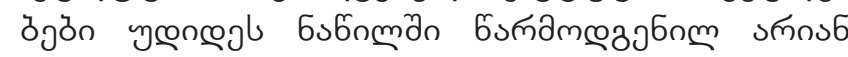

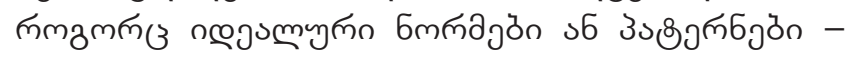

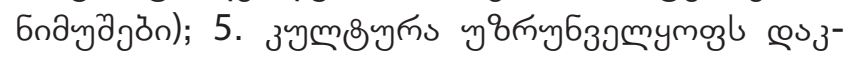

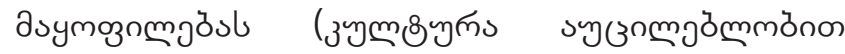
yony

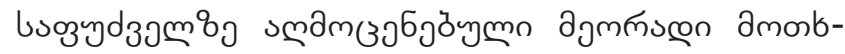

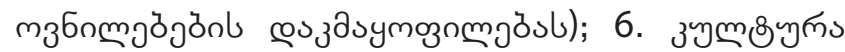

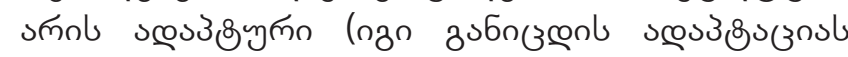

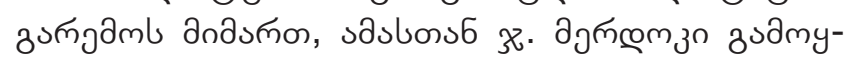

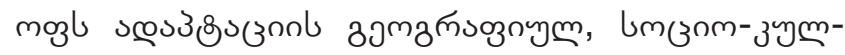

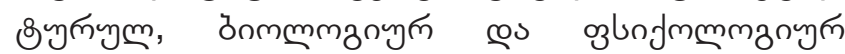

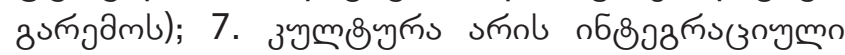

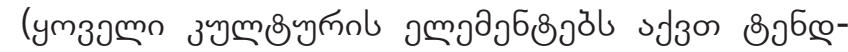

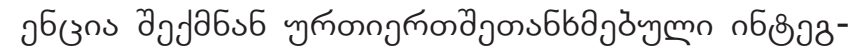

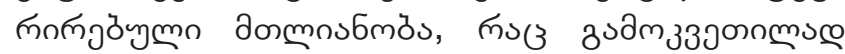

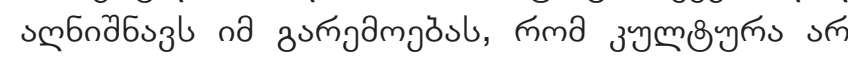

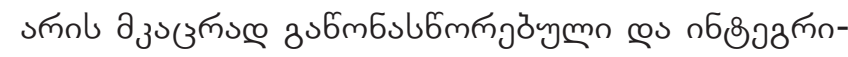
пூว̈ymo lnb $8 j a s)$.

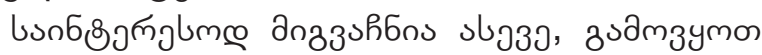

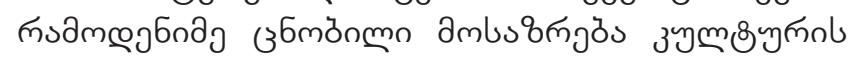

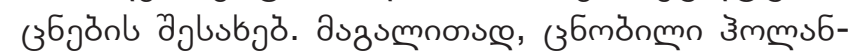

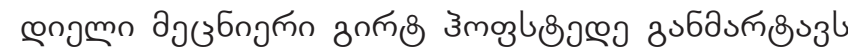

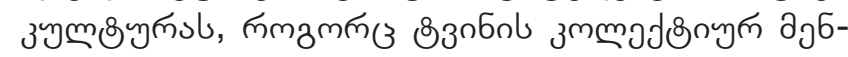

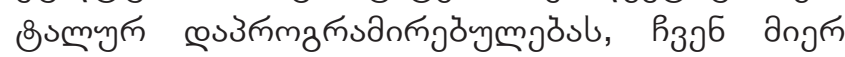

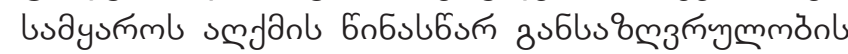

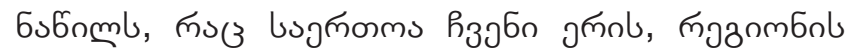

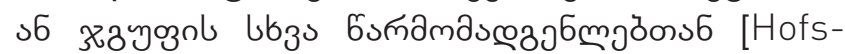

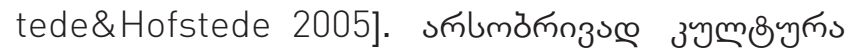

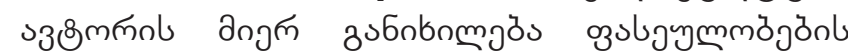




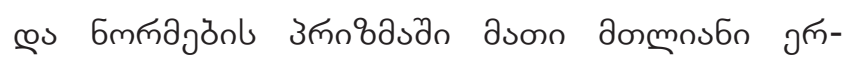

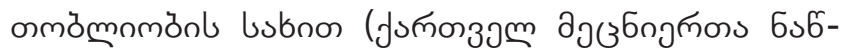

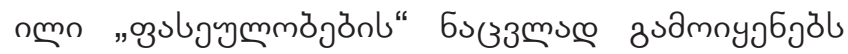

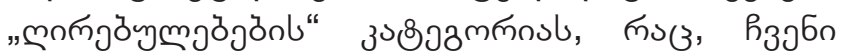

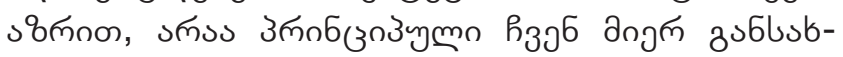

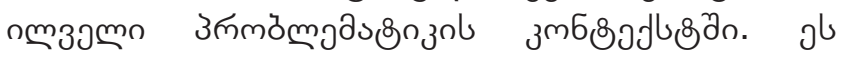

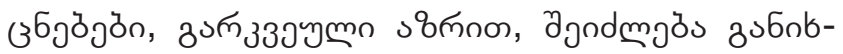

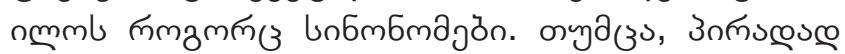

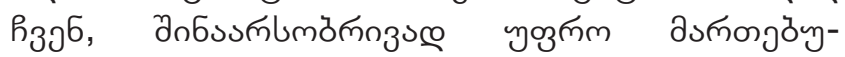

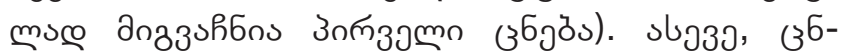

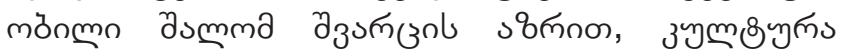

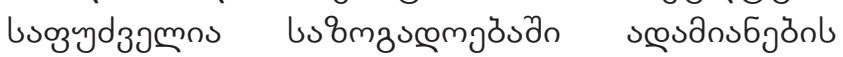

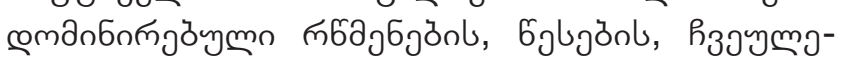

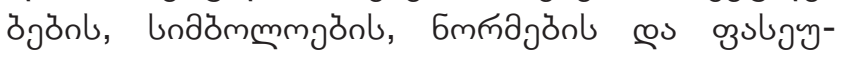

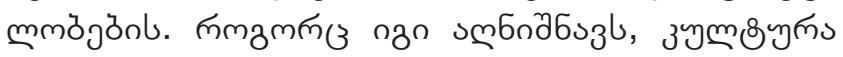
ง

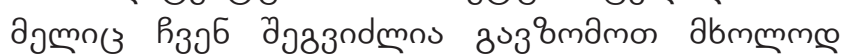

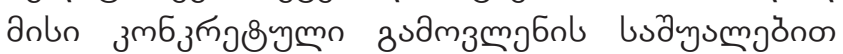

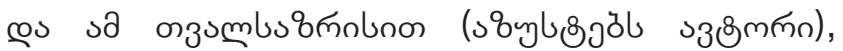

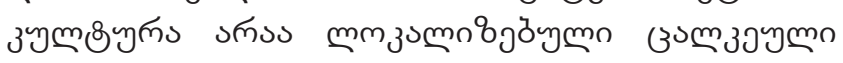

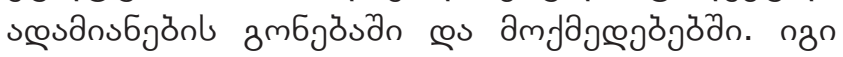

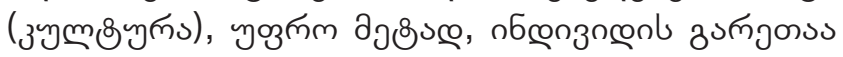

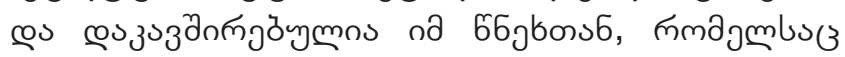

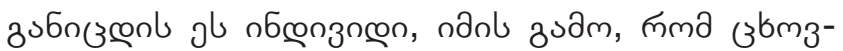

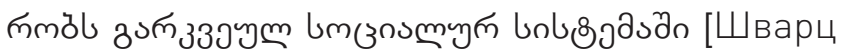
2008].

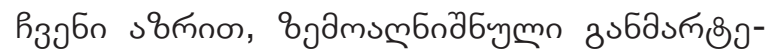

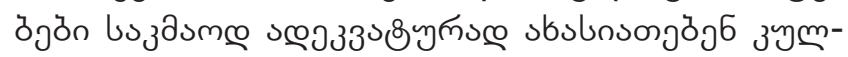

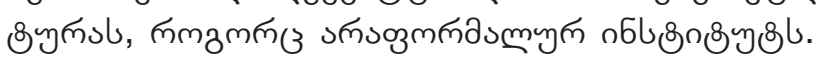

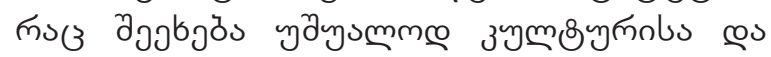

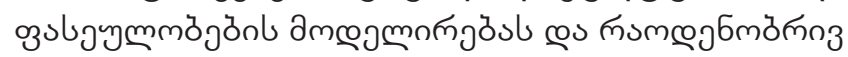

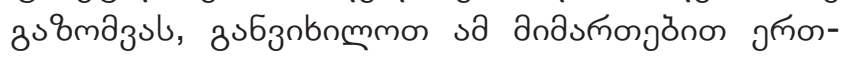

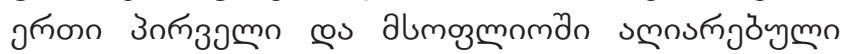

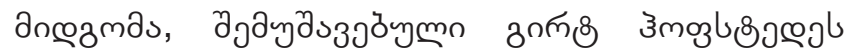
дngк. Зmoुl

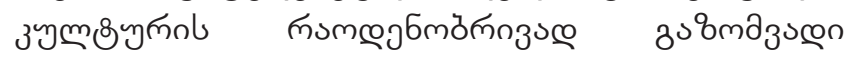

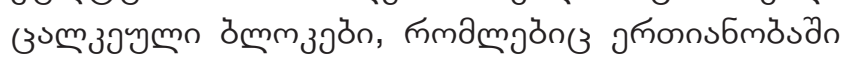

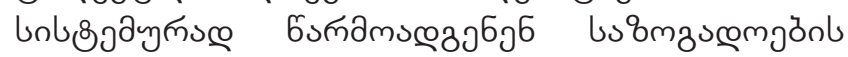

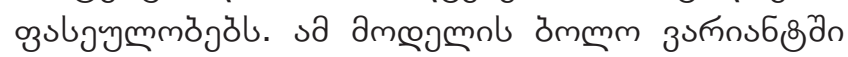

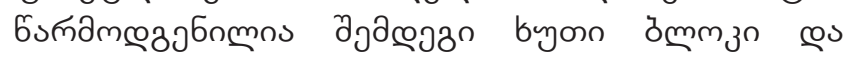

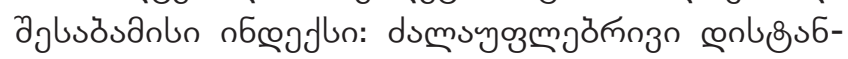
३ns (PDI - Power distance index) sbubszl sœ-

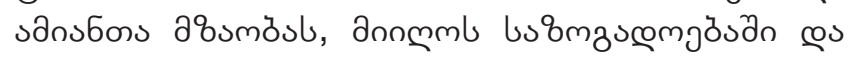

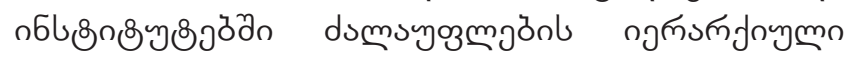

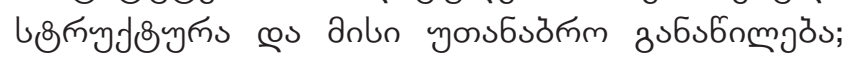

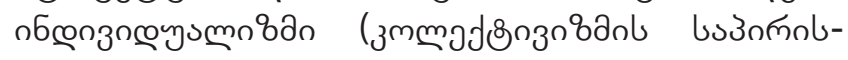
Зоп̆œе, IDV - Individualism vs. collectivism)

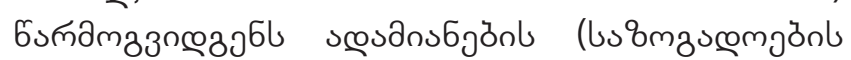

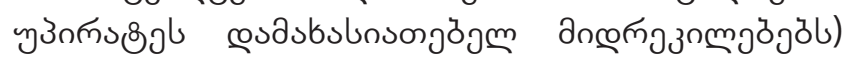

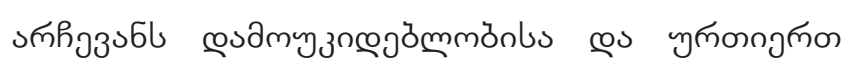

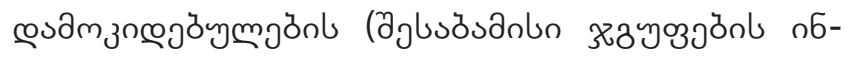

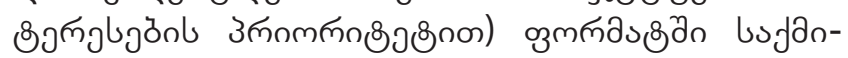

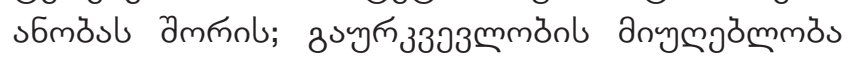

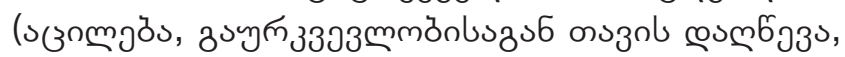

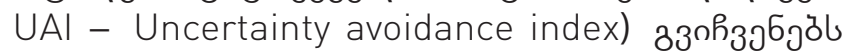

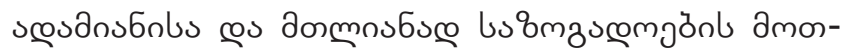

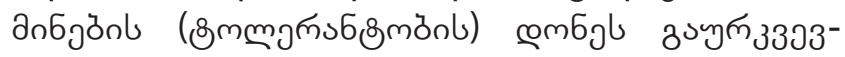

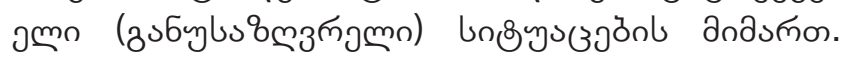

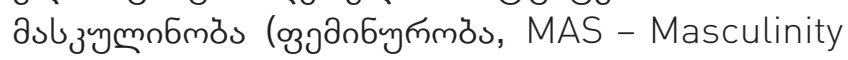
vs. Femininity) smol sœudns6jönl œs dommns6sœ

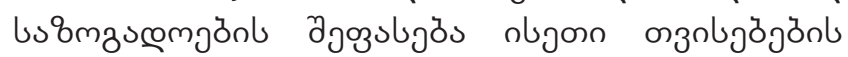

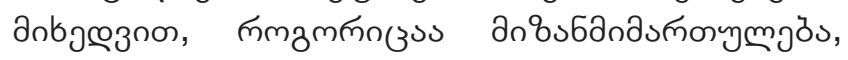

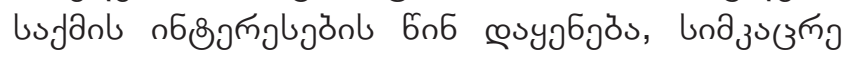

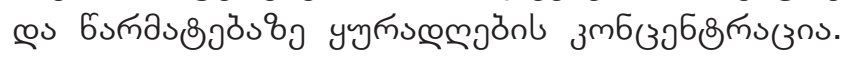

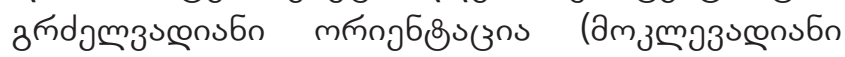
mnnj68su(zns, LTO - Long-term orientation vs.

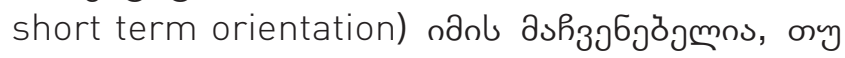

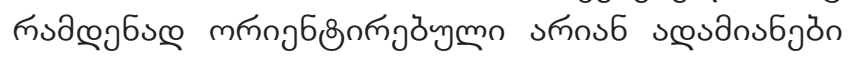

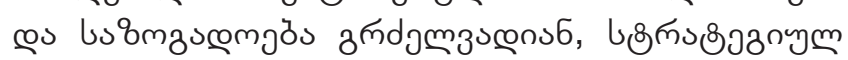

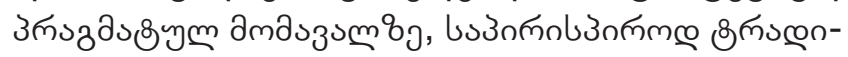

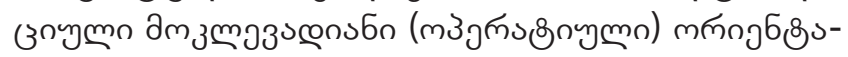

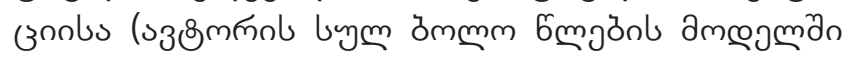

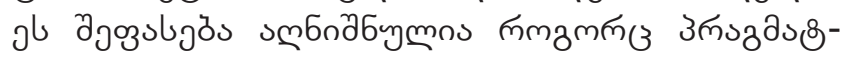

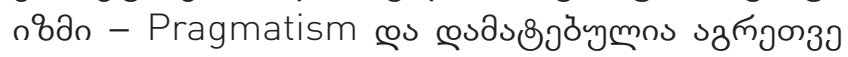

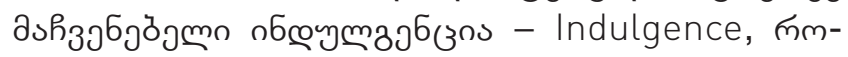

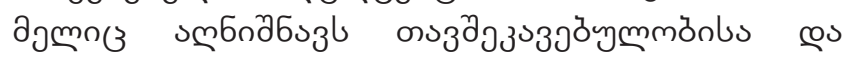

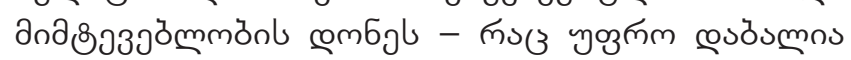

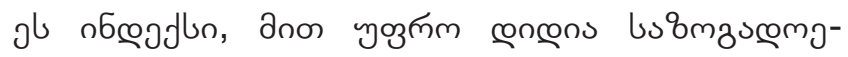

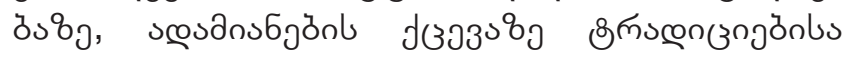

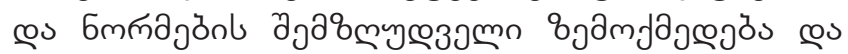

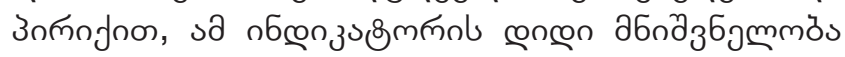

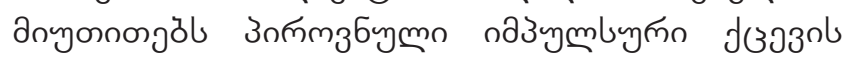

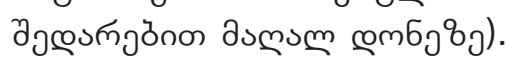

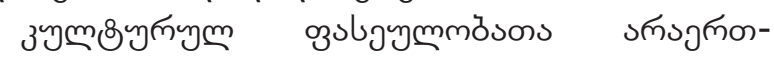

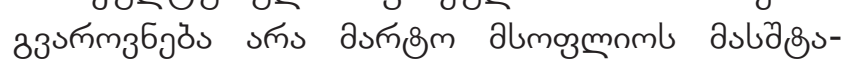

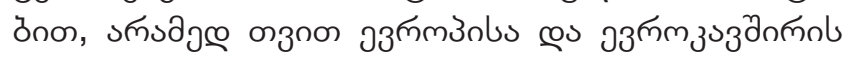

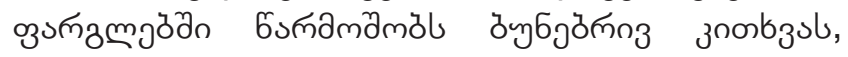

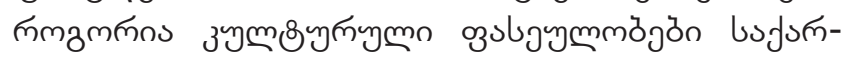

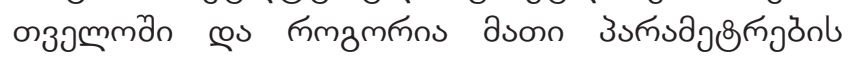

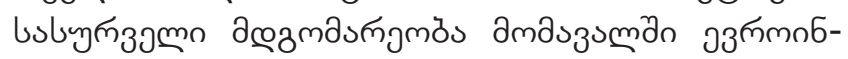

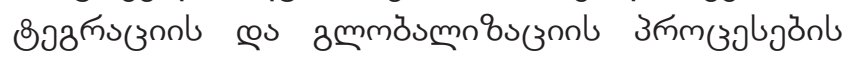

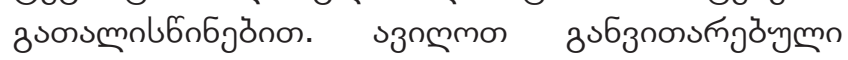

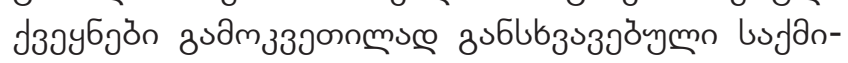

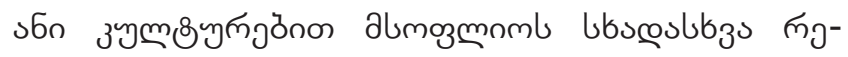

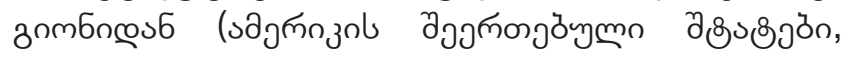

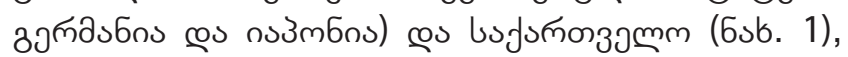

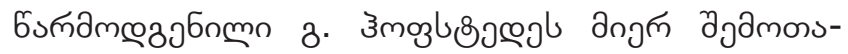

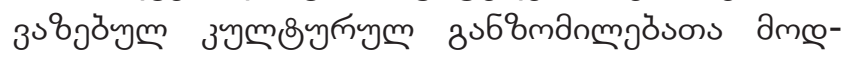




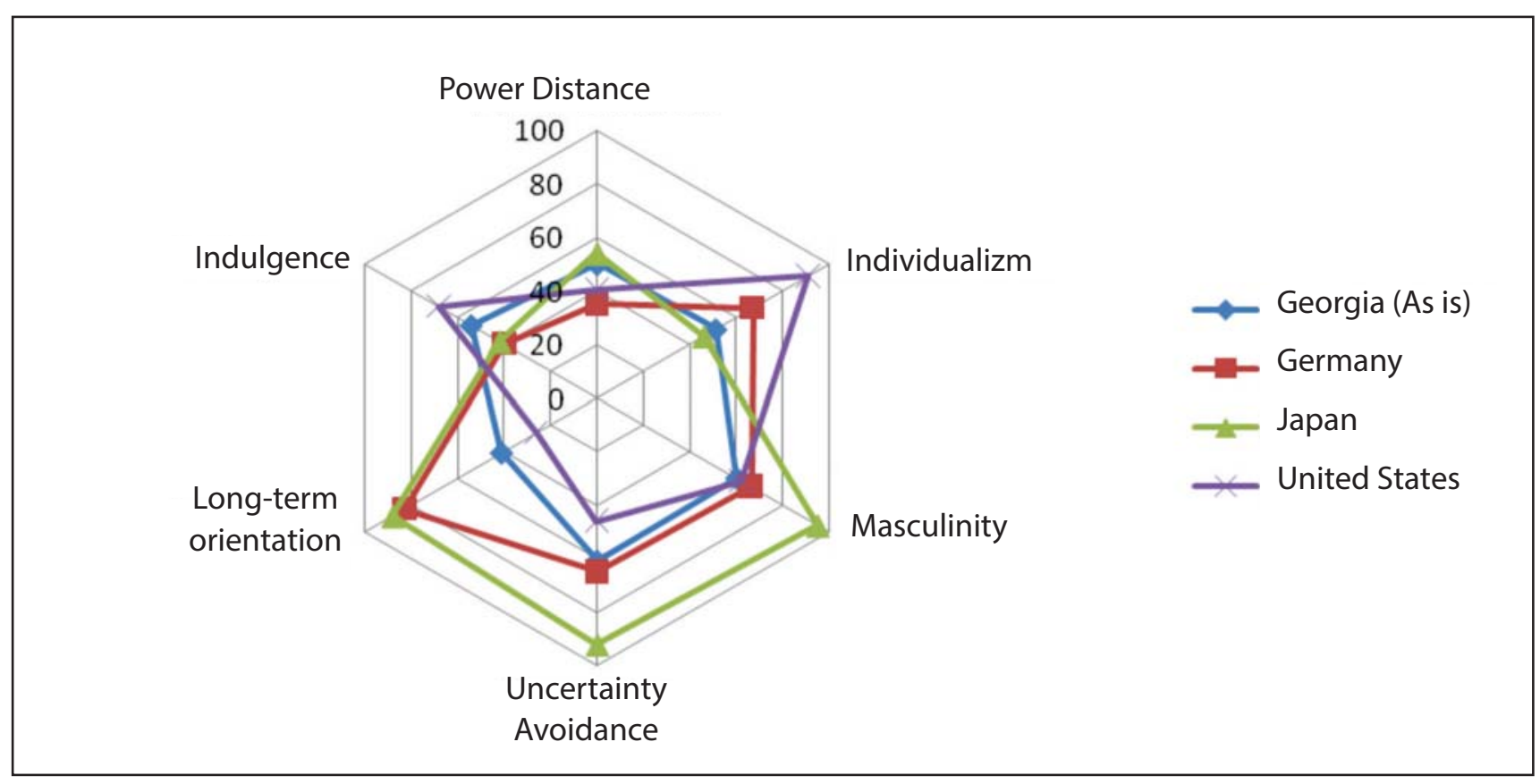

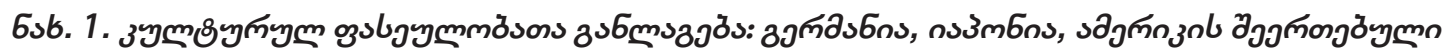

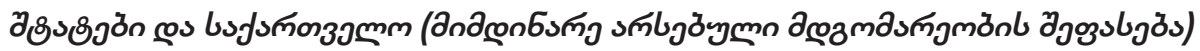

jmol [http://geert-hofstede.com] bsogyd $39 \mathrm{~m}$ \&o

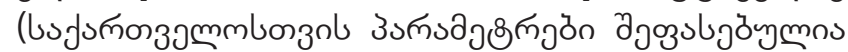

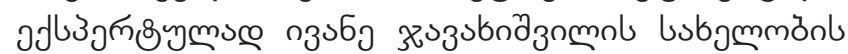

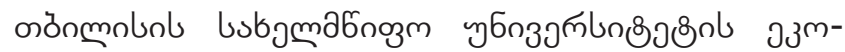

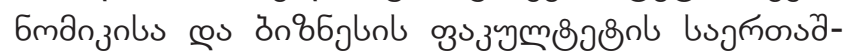

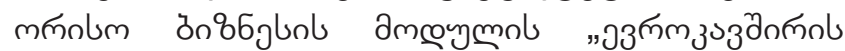

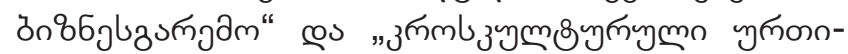

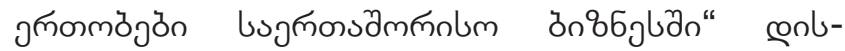

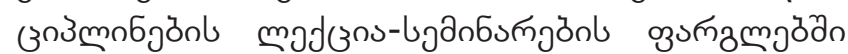

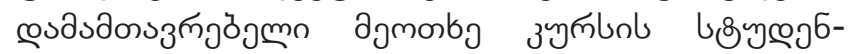

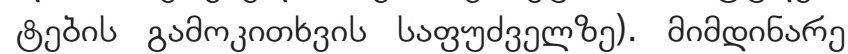

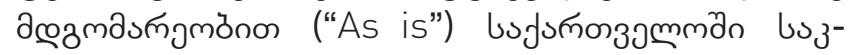

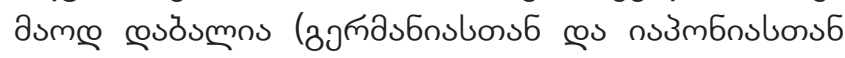

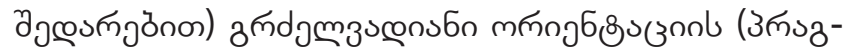

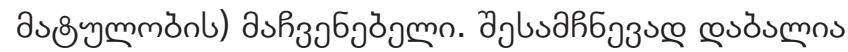

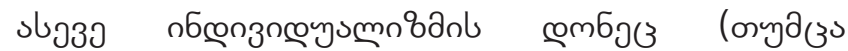

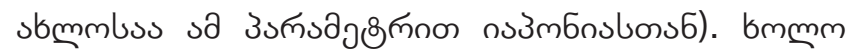

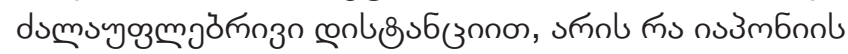

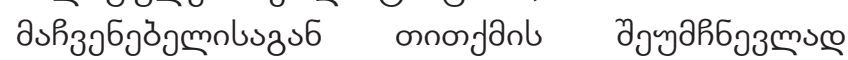

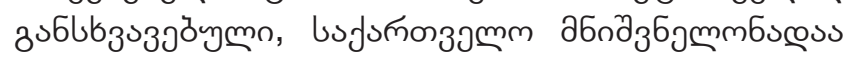

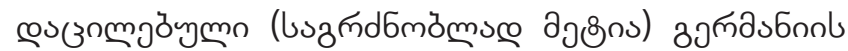

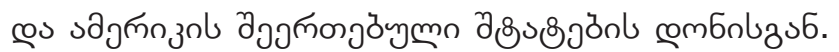

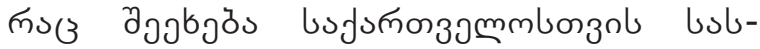

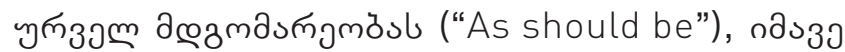

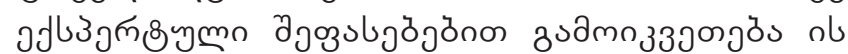

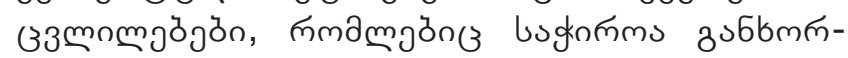

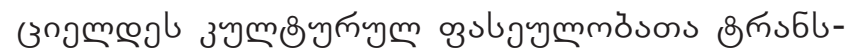

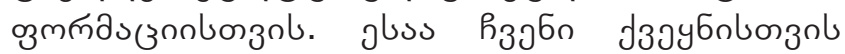

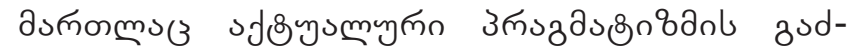

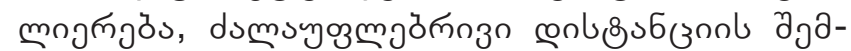

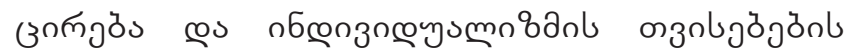

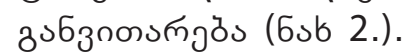

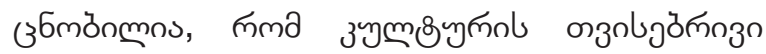

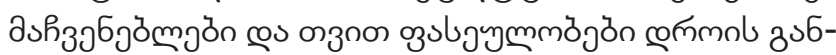

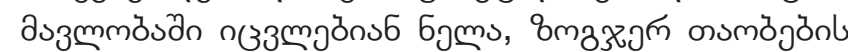

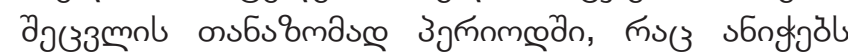

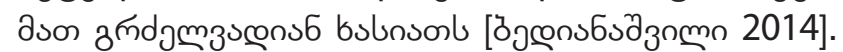

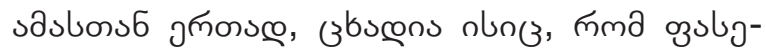

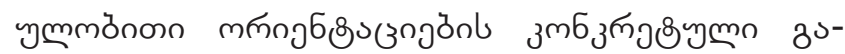

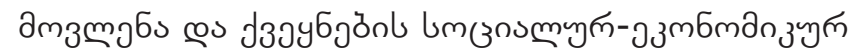

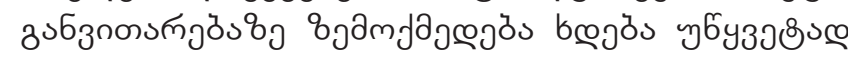

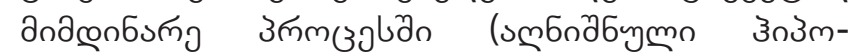

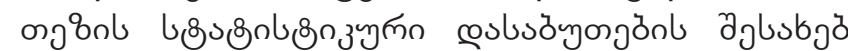

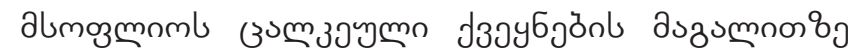
nb.: [Инглхарт, Вельцель 2011]).

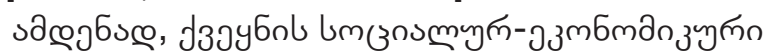

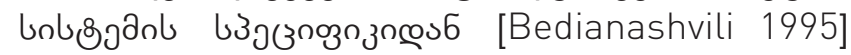

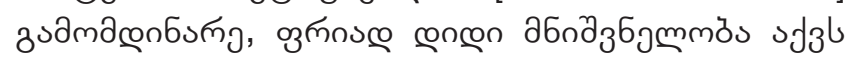

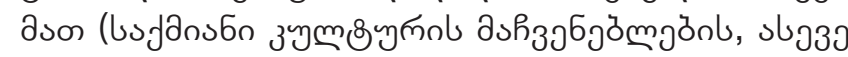

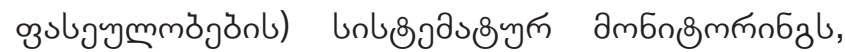

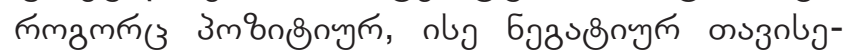

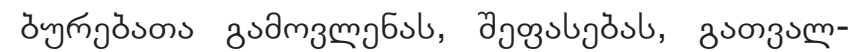

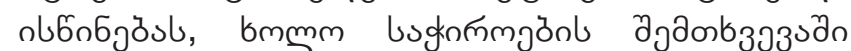

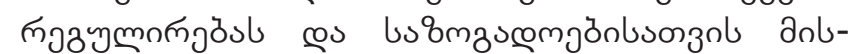

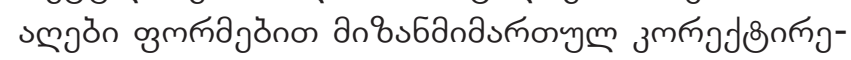

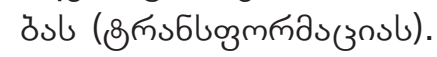




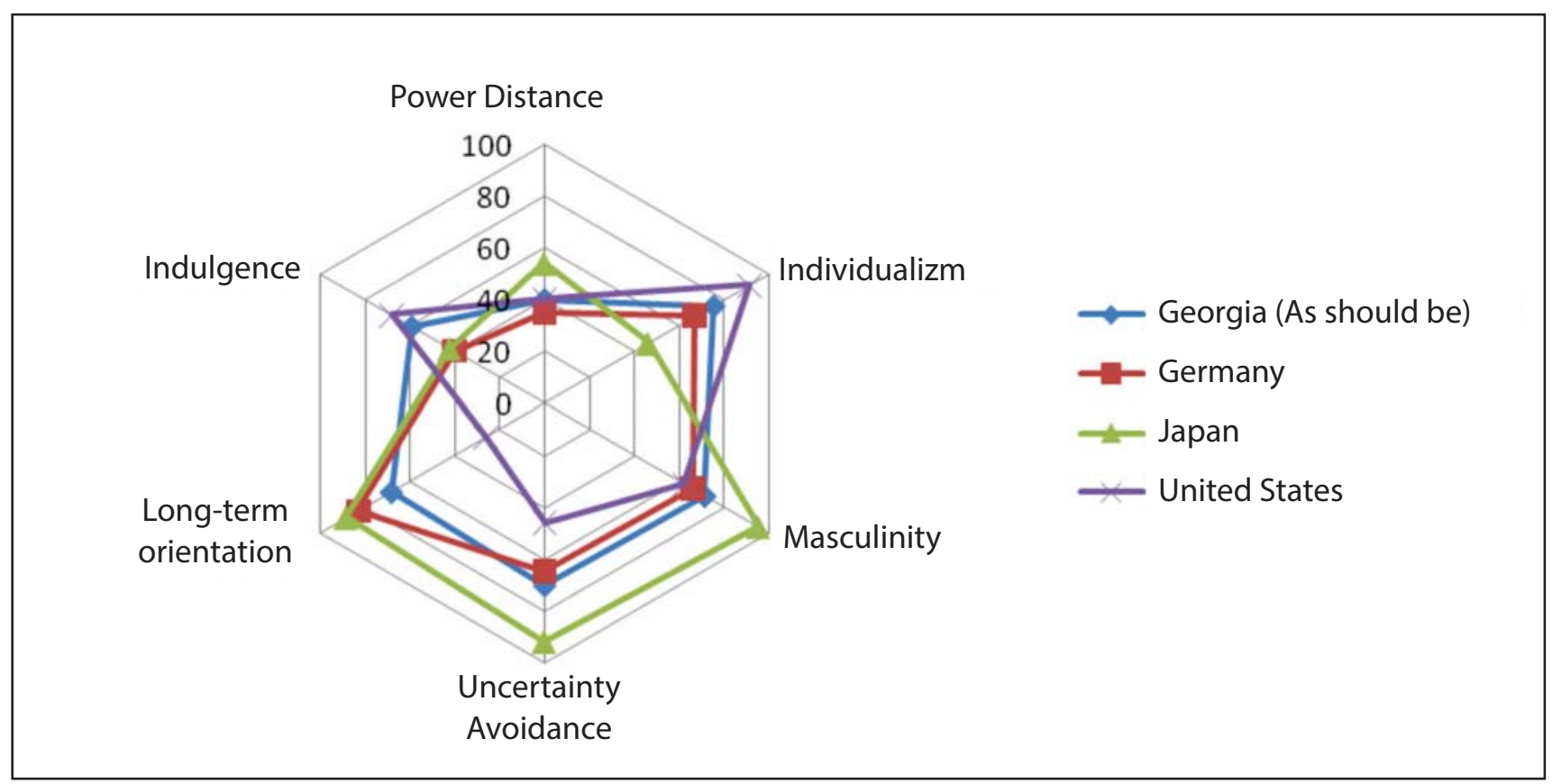

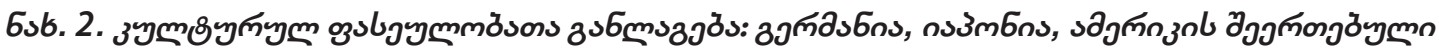

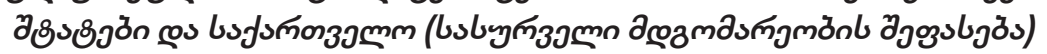

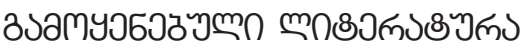

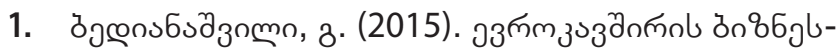

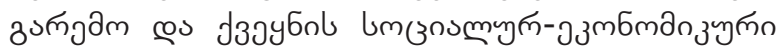

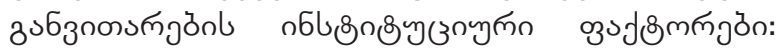

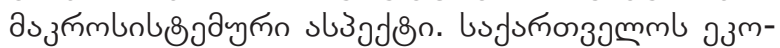

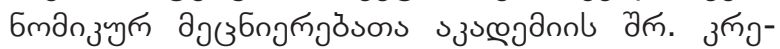
ठ̈ymn. вman 12, oర̉nmoln, 33. 82-95.

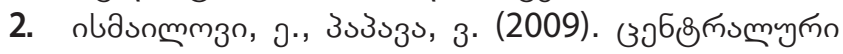
зงззง oỏnmoln: Lnstemg.

3. Беридзе, Т. (2007). Национальная экономическая модель: альтернатива глобализации? Журнал социально-политических и экономических исследований. Том 1 (3). CA\&CC Press. Швеция.

4. Harrison, A. (2014). Business Environment in a Global Context. Oxford University Press.

5. Hofstede, G. (1980). Culture's Consequences: International Differences in Work-Related Values. - Beverly Hills, CA: Sage Publications.

6. Triandis, H. (1994). Culture and Social Behavior. - N.Y.: McGraw-Hill.

7. Шварц, Ш. (2008). Культурные ценностные ориентации: природа и следствия национальных различий. Психология. Журнал Высшей школы экономики. Т. 5, №2. С.37-67.

8. Инглхарт, Р.Вельцель, К. (2011). Модернизация, культурные изменения и демократия. Последовательность человеческого развития. М.:
Новое, издательство.

9. Культура имеет значение. Каким образом ценности способствуют общественному прогрессу (2002). Под редакции Л. Харрисона и С. Хантингтона. М.

10. Hall, E., Hall, M. (1990). Understanding Cultural Differences. - Yarmouth ME: Intercultural press.

11. Тромпенаарс, Ф., Хампден-Тернер, 4. (2004). Национально-культурные различия в контексте глобального бизнеса. Минск.

12. Ясин, Е. (2008). Исследование культурных ценностей - общее дело социальных наук. Психология. Журнал Высшей школы экономики. Т. 5, №2. С.25-36.

13. Аузан, А. и др. (2011) Культурные факторы модернизации. М., Санкт-Петербург.

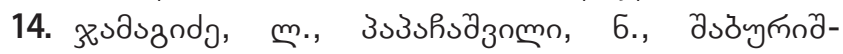

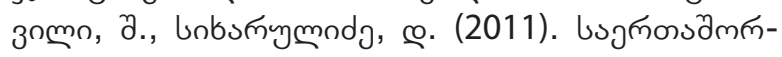

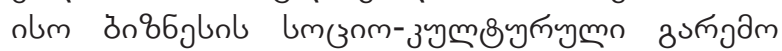

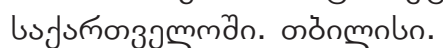

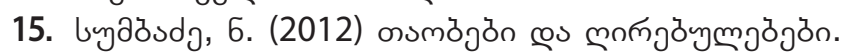
mònmolon.

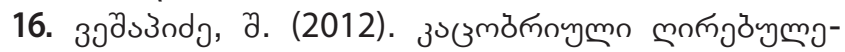

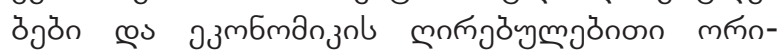

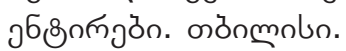

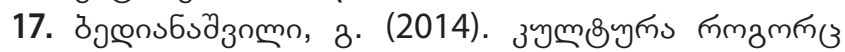

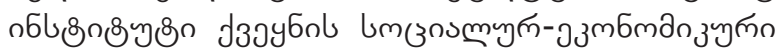

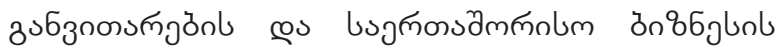




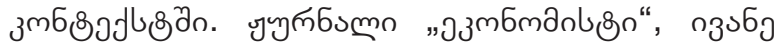

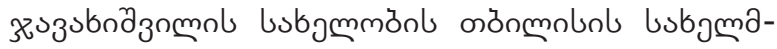

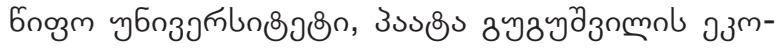

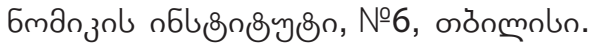

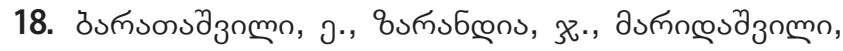

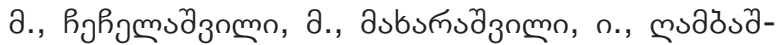

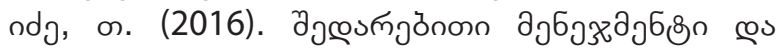

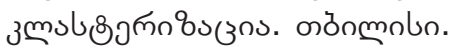

19. Тамбовцев, В. (2014). Экономическая теория неформальных институтов. М.:РГ-Пресс.

20. North, D.C. (1994). Economic Performance through Time //American Economic Review. Vol. 84. No. 3. P. 361.

21. Gladwin, T. N. and Terpstra V. (1978). Introduc- tion In Cultural environment of international business / Ed. by V. Terpstra, Cincinnati: Southwestern, p. xiv.

22. Murdock, G. P. (1965). Culture and Society. University of Pittsburgh Press.

23. Hofstede, G. \& Hofstede, G.J. (2005). Cultures and Organizations. Software of the Mind (2nd edn). New York: McGraw-Hill.

24. http://geert-hofstede.com.

25. Bedianashvili, G. (1995). State, Power Structure and Social-Economic Reforming of Society. P. Gugushvili Institute of Economics of the Georgian Academy of Sciences. Tbilisi: Metsniereba.

\title{
The Global Business Environment, European Integration and the Cultural Potential of Social-economic Development of Georgia
}

https://doi.org/10.35945/gb.2016.01.002

\author{
Givi Bedianashvili \\ Doctor of Economic Sciences, \\ Professor European Teaching University; \\ Ivane Javakhishvili Tbilisi State University, Visiting Professor \\ Academician of the Academy of Economic Sciences of Georgia
}

Key words:

GLOBALIZATION, EUROPEAN INTEGRATION, CULTURAL POTENTIAL

\section{Summary}

Based on the characteristics of the global business environment, discusses the importance of the cultural factor for social and economic development of Georgia in the process of European integration today. Given the informal institutional nature of the culture, it justified its multidimensionality. Using G. Hofstede's model, on the basis of expert measurements are shown for Georgia the status quo of cultural values and the direction of the desirable change. 